\title{
Oviposition behavior and host records for the parasitic midge Trichochilus lacteipennis (Johannsen) (Chironomidae: Orthocladiinae)
}

\author{
David H. Funk ${ }^{1}$, Sherman L. Roberts ${ }^{1}$ and Alan C. Graham ${ }^{2}$ \\ ${ }^{1}$ Stroud Water Research Center, 970 Spencer Rd., Avondale, Pennsylvania, 19311, USA. \\ ${ }^{2}$ Alan C. Graham, PO Box 141, South Pomfret, Vermont, USA. \\ E-mails:dfunk@stroudcenter.org,sroberts@stroudcenter.org,alan.c.graham@gmail.com
}

\begin{abstract}
Adult female Trichochilus lacteipennis were observed to extrude long strings of eggs (up to $15 \mathrm{~cm}$ ) in flight over a lake in Maine, USA. Once extruded females dropped to the water surface and released the strings. Larvae of T. lacteipennis are parasitic on Elliptio complanata at this site and probably additional unionid mussel species elsewhere. Based on our dissections of parasitized mussels and previous reports, it appears T. lacteipennis spend all or nearly all of their larval life within their mussel host, with first instars initially free-living inside the mantle. At some point larvae enter the marsupium and complete larval development on a diet of mussel eggs and/or glochidia before pupating within the marsupium.
\end{abstract}

\section{Results}

On still mornings between 0700 and 0900 from 17 to 21 June, 2015, we observed an unusual oviposition behavior by a (then) undetermined species of Orthocladiinae over Lake Umbagog, along the New Hampshire/Maine border (USA; $\left.44.8038^{\circ} \mathrm{N}, 71.0072^{\circ} \mathrm{W}\right)$. Females were seen flying from the nearby riparian forest canopy each slowly extruding a long string of eggs (Figs 1-2; also, cover of Chironomus Journal of Chironomidae Research, Vol. 29 [2016]). This extrusion lasted up to several minutes as the midges hovered from 2-10 m over the water surface, from near the shore to about $50 \mathrm{~m}$ offshore. Strings up to $15 \mathrm{~cm}$ in length were extruded, after which females dropped to the water surface, released the strings, then flew off.

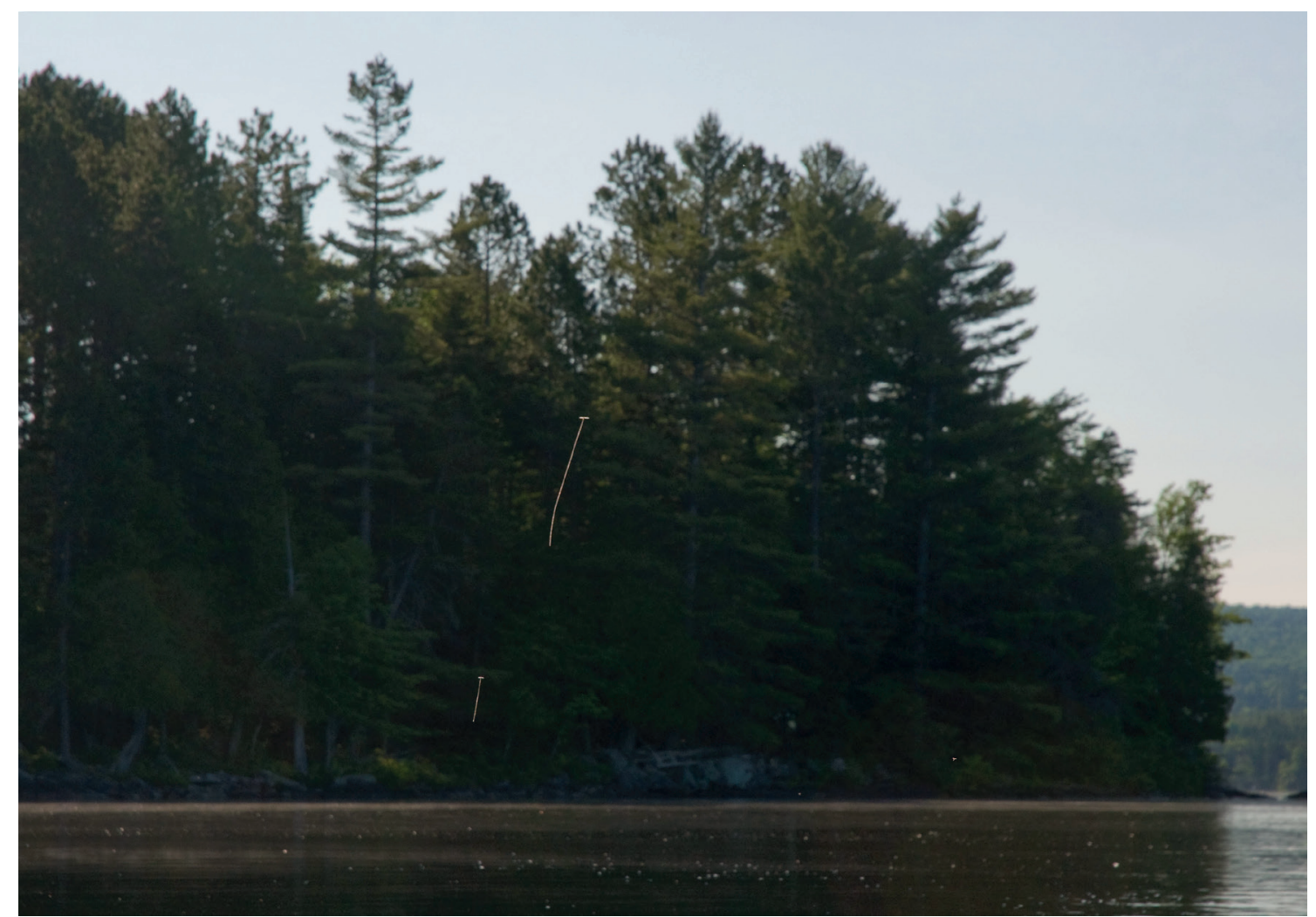

Figure 1. Two adult female Trichochilus lacteipennis hovering over Lake Umbagog, in the process of extruding strings of eggs. 


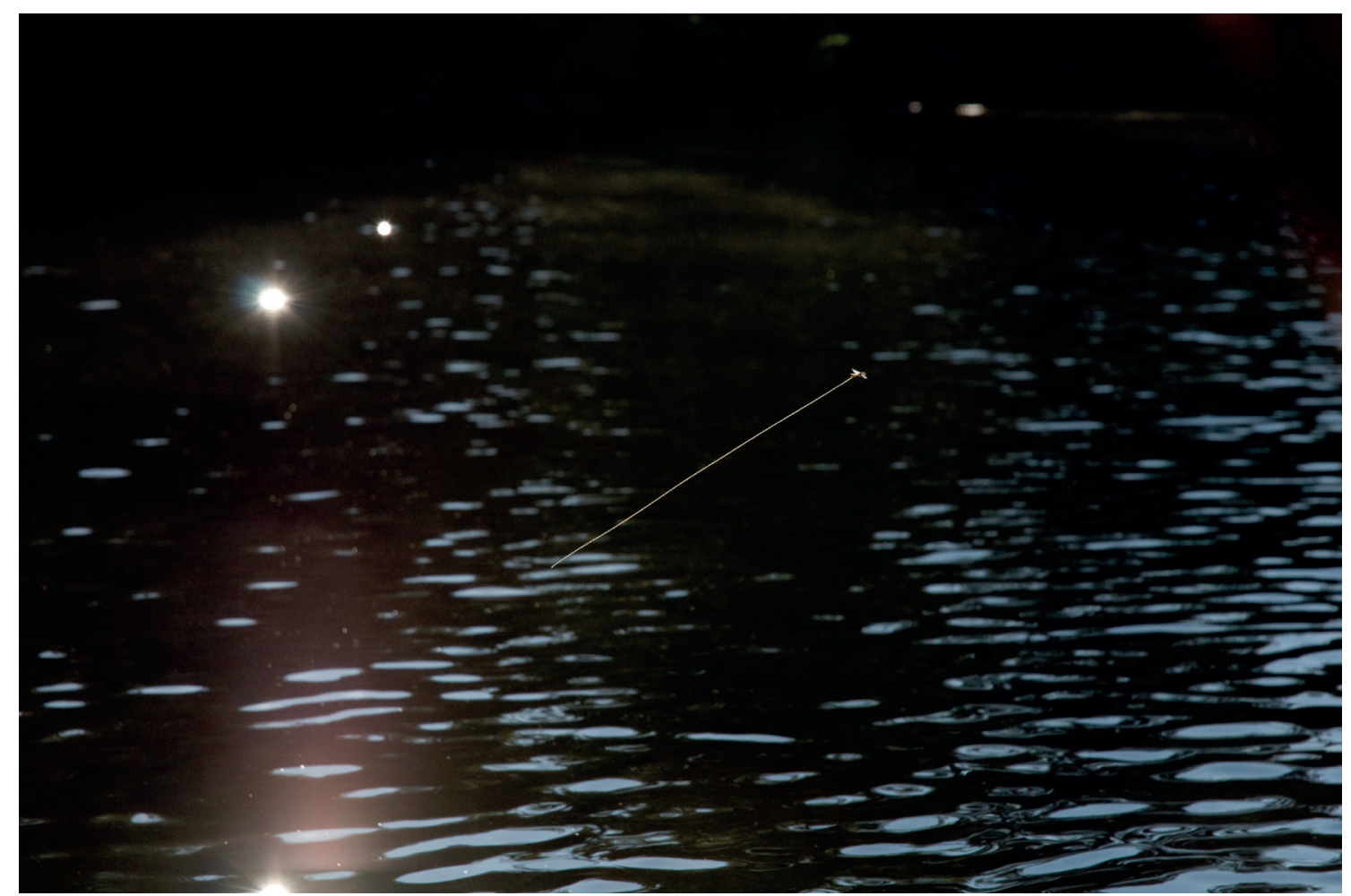

Figure 2. A female Trichochilus lacteipennis with egg string fully extruded, as it descended toward the water surface just prior to releasing the eggs.

Backlit by the low morning sun and observed against the dark, shady, mostly coniferous riparian forest, individual midges with their egg strings could be seen easily from distances up to $170 \mathrm{~m}$. Three ovipositing females were collected and preserved in ethanol. All three were subsequently sequenced for COI (two by BOLD and one at the Stroud Water Research Center; see Appendix). Two individuals had identical haplotypes and the third differed by about $5 \%$, suggesting the possibility of more than one species. No close matches to either haplotype were found in existing databases.

On June 19-25, 2016, the collection site was revisited. Once again, many ovipositing females were observed on calm mornings between 0700 and 0900. One of us (Roberts) recorded video and another (Funk) recorded still images of the oviposition behavior. These were later combined into a video that was posted on YouTube (https://www.youtube.com/watch?v=z2ugoE1y15o). Egg strings from two individuals were collected into separate $30 \mathrm{ml}$ sample bottles filled with filtered $(0.45 \mu)$, sterilized stream water from White Clay Creek, Pennsylvania, USA (Fig. 3). These were stored in a cooler (temperature ranging from $10-15^{\circ} \mathrm{C}$ ) for 5 days, then transferred to a $20^{\circ}$ water bath and a 15:9 (light:dark) photoperiod for 6 weeks, during which time no development was observed. At the end of this period the eggs appeared to be dead, although there was no obvious microbial activity. Nevertheless, both vessels were then stepped down to $4^{\circ}$ (at constant darkness) for 5 months to simulate a "winter", then stepped back up to $20^{\circ}(15: 9)$. By this time the eggs were clearly dead.

In January, 2017 four female specimens (including the three 2015 specimens with known COI sequences plus a fourth unsequenced specimen from 2016) were sent to Martin Spies in Munich, Germany, who was able to identify them as Trichochilus lacteipennis (Johannsen). These specimens now reside in the Bavarian State Collection of Zoology (ZSM = Zoologische Staatssammlung München).

The genus Trichochilus was erected by Sæther (1985) for Trichochilus lacteipennis (Johannsen, 1908), at that time known only from the adult female holotype. In the 1990s Matthew Gray, then an undergraduate student at the University of Pittsburgh, sent pupal exuviae, pupae, males, and females to William Coffman for identification. These had been reared from larvae found in gills (and presumably feeding on glochidia) of the unionid mussel Elliptio complanata in Ansonia, Pennsylvania, USA. Dr. Peter H. Langton (who was visiting Coffman at the time) identified the females as Trichochilus lacteipennis. Coffman gave the material to Rick Jacobsen for description, and a manuscript is now in preparation. Epler (2001) and Andersen et al. (2013) provided figures and descriptions of larvae based on this material. 




Figure 3. A string of Trichochilus lacteipennis eggs suspended in water near the bottom of a glass rearing vessel.

We visited the Lake Umbagog site again from 18-24 June, 2017, with the intent to collect more Trichochilus eggs and adults, and to look for their immatures in Elliptio complanata, which we knew to be abundant in the lake. Weather during all 5 mornings of our 2017 stay was windy and/or rainy during the 0700-0900 window within which we had observed oviposition flights in previous years. Probably for this reason, only a few ovipositing Trichochilus were seen, and only one captured. The egg strings extruded by these females were much shorter than those observed in previous years. Long strings such as those in Figs 1-2 must surely present a great deal of wind resistance, thus requiring relatively still conditions for controlled flight. The single string collected in 2017 was placed in a $30 \mathrm{ml}$ vessel similar to the ones used in 2016, but this time containing unfiltered water from Lake Umbagog. This vessel was stored in a cooler until 27 June when it was transferred to a $20^{\circ}$ (15:9 photoperiod) water bath in the lab. By 30 June most eggs had hatched.

We also searched for pupal exuviae by skimming the water surface near the lake margin with a small aquarium net on several occasions during the 2017 visit. Several species of Chironominae and Tanypodinae were abundant in these collections. Only 7 orthoclads were found and all turned out to be Trichochilus.

In addition, 118 Elliptio complanata and one Pyganodon sp. were collected from the vicinity of the oviposition site. Adductor muscles were severed with a scalpel and the clams opened. For each individual, tissues were first flushed with a jet of lake water into a small pan and carefully examined for the presence of chironomids. Then all the larger bodies of soft tissue were incised and examined for the presence of chironomids within. Nine Elliptio contained Trichochilus (total: 19 larvae and 25 pupae, most with associated larval exuviae). All chironomid specimens were preserved in 95\% ethanol. Shells from mussels that contained Trichochilus were collected and dried, and small samples of foot tissue were preserved in $95 \%$ ethanol. All Trichochilus larvae were mature, some showing pupal structures within. All pupae appeared to 
have transformed only recently (none were pharate). Trichochilus larvae and pupae were found only within the outer, marsupial gill lamellae and were revealed by incision of this structure (Fig. 4). When more than one individual was present (up to 6 were found in a single lamella) these were conspicuously clustered in the dorsal portion of that lamella. Larval structures of these specimens match the figures and descriptions by Epler (2001) and Andersen et al. (2013).

Gordon et al. (1978) reported parasitic relationships between another orthoclad, Baeoctenus bicolor Sæther, 1976, and the unionids Pyganodon cataracta and Anadonta implicata from a reservoir in New Brunswick, Canada. Baeoctenus larvae appeared to invade mussels in late winter as 3rd instars and actively feed on gill tissue. They reached 4th instar around ice out and pupated in late May or early June, with emergence completed by late June or early July. Both larvae and pupae inhabited tubes constructed of particulate organic material, and were normally attached to anterodorsal surfaces of the gills near the labial palps of $P$. cataracta. As many as 3 larvae were found on the same gill and feeding damage was evident, with as much as $50 \%$ of gill tissue absent.

In addition to Baeoctenus bicolor, Gordon et al. (1978) found a total of 860 larvae of another, unknown orthoclad ("near Phycoidella") in Pyganodon cataracta (but not in three other unionids examined, including Elliptio complanata). These larvae were collected by severing the mussels' adductor muscles and washing the tissues with a jet of water over a dish. Only first instars were found and these had a similar seasonal pattern of occurence as Baeoctenus, "with a substantial decrease in June, followed by a sharp rise throughout July and early August." The apparent absence of any later instars or evidence of feeding damage led the authors to postulate that the association was not parasitic and that the larvae left the mussels to pass the remaining instars elsewhere. Roback (1979) provided figures and a description of these first instar larvae (as "Genus near Phycoidella" sensu Sæther) based on the collections by Gordon et al. (1978) as well as on material from five genera of unionids collected in Louisiana. Epler (2001) considered these to be Trichochilus despite some differences between Roback's (1979) description and the fourth instar Trichochilus larvae from Pennsylvania, e.g. the presence of a "comb-like row of preapical setae" on the mandible in Roback's first instars, which Epler suggested might disappear in later instars. Our Trichochilus hatchlings are similar



Figure 4. Four Trichochilus lacteipennis pupae revealed by incision of the outer lamella (marsupium) of the right gill of an Elliptio complanata. 
to the brief description given by Roback (1979) (including the presence of the "comb-like row of preapical setae"), except that each anterior proleg on our specimens has one very conspicuous comb-like claw in addition to three large simple ones (plus some smaller structures basally). Thus, our observations confirm Epler's (2001) suggestion that the mandibular setae disappear in later instars. Similar to the final instar, the ventromentum in our specimens is toothless and the dorsomentum has 5 teeth on each side. Not mentioned by Roback but evident in our specimens, the S I setae are simple (as in the final instar) and the premandible has at least 4 teeth.

Given all the above evidence, it seems likely that Trichochilus spend all or nearly all of their larval life within their mussel host, starting with first instars free-living inside the mantle and later entering the marsupium to complete larval development (rather than beginning life in some other habitat). If this is true, one is left to wonder why Gordon et al. (1978) did not find later instars or pupae. A clue may be found in their Methods section: larvae were collected by severing the mussels' adductor muscles and washing the tissues with a jet of water over a dish; no indication is given that they examined the contents of the marsupium. The 4th instars and pupae we found in Elliptio complanata were only revealed by incision of the marsupium. It therefore seems possible that later stages were present inside the marsupium of Pyganodon cataracta in June but were overlooked by Gordon et al. (1978). Another, much less plausible, explanation is that first instars leave Pyganodon cataracta and enter Elliptio complanata to complete their larval lives. Gordon et al. (1978) examined 67 Elliptio complanata during the infestation period (using the same washing technique as in Pyganodon) and reported the absence of midge larvae or pupae, but again, presence of the latter within the Elliptio marsupium might have been missed.

We did not find any first instar Trichochilus in the Elliptio complanata mussels examined in 2017. As these dissections were performed in the field, without a microscope, it is possible that first instars were overlooked. However, considering what we know of their seasonality it seems likely that only fourth instars and pupae would be present inside mussels during that time period (18-24 June).

Although the diet of first instars is unknown, at some point in their development Trichochilus larvae clearly become parasitic. Guts of fourth instars were full of mussel eggs and/or glochidia. Nevertheless, we thought it worth a try to start some of our hatchlings out on a diatom/biofilm diet. We placed approximately 50 each in two vessels with some filtered $(200 \mu)$ periphyton slurry and an air stone at $20^{\circ}$ (15:9 photoperiod). None survived for more than a couple of days.

Although the production of gelatinous strings of eggs is widespread in the Chironomidae (Nolte 1993), these are generally produced at or near the water's surface, and attached to stones or other objects. To our knowledge the extrusion of long strings of eggs in flight is reported here for the first time (although something similar was recently observed in Hydrobaenus biwaquartus (Sasa \& Kawai, 1987); Hongqu Tang, personal communication). Trichochilus egg strings sank slowly in our test vessels, appearing to be only slightly denser than the water. They did not stick to the glass, but remained in suspension near the bottom of the vessel. If they behave similarly in the lake it is likely that they drift around with the currents near the lake bottom and might eventually enter the siphon of a mussel. Given the failure of eggs collected in 2016 to hatch, we had hypothesized that egg strings might need to enter and become lodged in the gills of a mussel in order to stimulate hatching. However, the fact that eggs collected in 2017 hatched quickly in a glass vessel of lake water leads us to reject that hypothesis. Thus, the significance (if any) of the unusual method of oviposition observed in Trichochilus remains unclear.

Pending the availability of resources, we plan to sequence mitochondrial COI for the 44 immature specimens collected from Elliptio in 2017. This data might prove helpful in the interpretation of the considerable morphological variation evident in available specimens (R. Jacobsen and M. Spies, personal communication), as well as provide a measure of genetic diversity and possibly the demographics of infection.

\section{Acknowledgements}

Martin Spies identified our adult female Trichochilus lacteipennis and provided an early review that greatly improved this manuscript. Rick Jacobsen alerted us to the collections made by Matt Gray, and shared his knowledge of this species and its associations.

\section{References}

Andersen, T., Cranston, P.S., and Epler, J.H. 2013. The larvae of Chironomidae (Diptera) of the Holarctic region - Keys and diagnoses. Insect Systematics and Evolution Supplement 66, Scandinavian Entomology, Lund, 571p. 
Epler, J.H. 2001. Identification Manual for the larval Chironomidae (Diptera) of North and South Carolina. A guide to the taxonomy of the midges of the southeastern United States, including Florida. (Special Publication SJ2001-SP13). North Carolina Department of Environment and Natural Resources, Raleigh, NC, and St. Johns River Water Management District, Palatka, FL., 526 pp.

Gordon, M.J., Swan, B.K. and Paterson, C.G. 1978. Baeoctenus bicolor (Diptera: Chironomidae) parasitic in unionid bivalve molluscs, and notes on other chironomid-bivalve associations. - Journal of the Fisheries Research Board of Canada 35: 154-157.

Nolte, U. 1993. Egg masses of Chironomidae (Diptera). - Entomologica Scandinavica, Supplement 43: $1-75$.

Roback, S.S. 1979. New record and hosts for Genus nr. Phycoidella Sæther (Diptera: Chironomidae: Orthocladiinae). - Entomological News 90 (5): 230-240.

Sæther, O.A. 1985. Trichochilus, a new genus of Orthocladiinae (Diptera: Chironomidae). - Spixiana Supplement 11: 31-36.

Article submitted 10. January 2018, accepted by Torbjørn Ekrem 2. February 2018, published 7. February 2018. 